
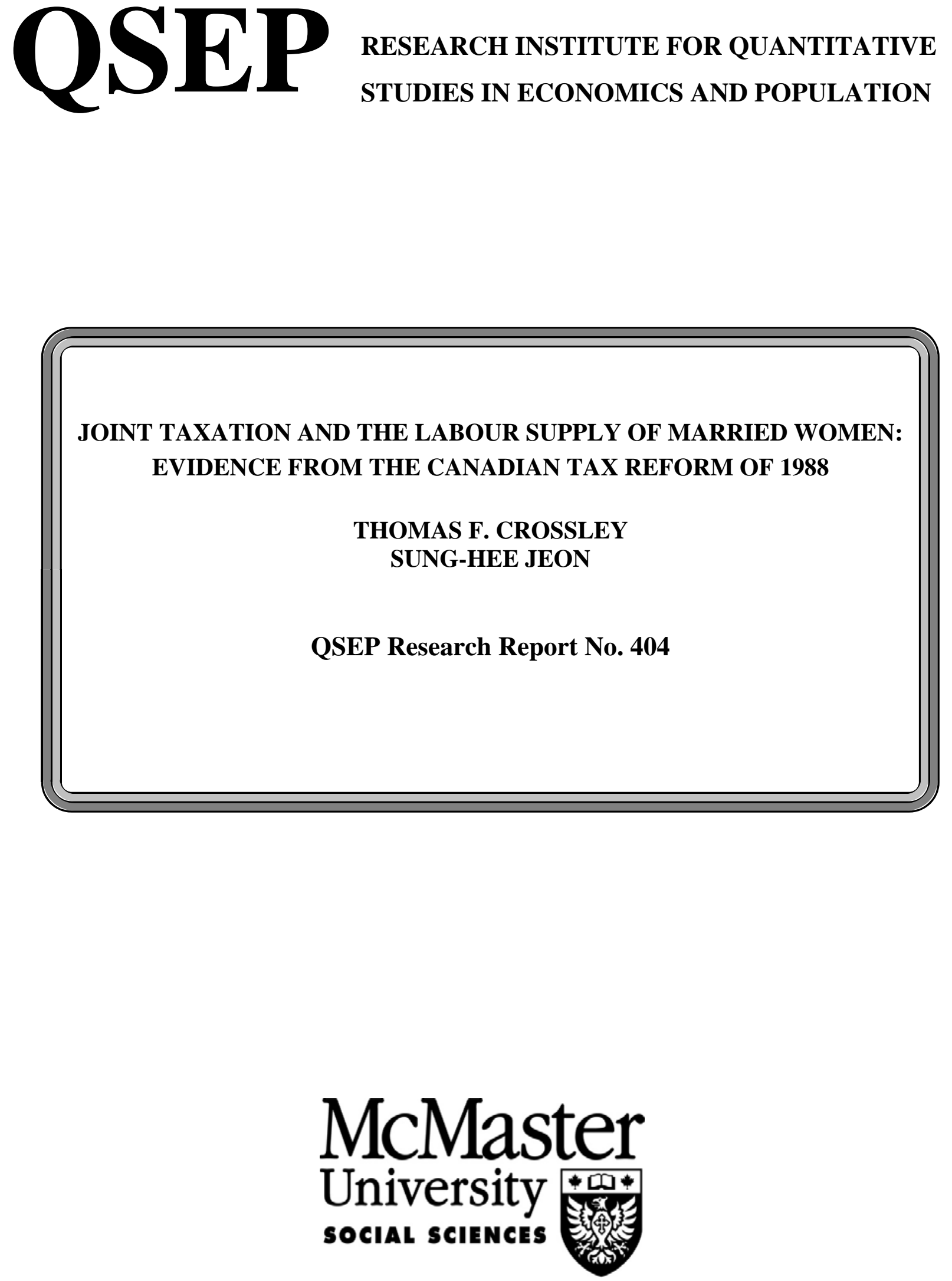
JOINT TAXATION AND THE LABOUR SUPPLY OF MARRIED WOMEN: EVIDENCE FROM THE CANADIAN TAX REFORM OF 1988

THOMAS F. CROSSLEY

SUNG-HEE JEON

QSEP Research Report No. 404

February 2006

This report is cross-listed as No. 149 in the McMaster University SEDAP Research Paper Series.

Thomas F. Crossley is a QSEP Research Associate and a faculty member in the McMaster University Department of Economics. Sung-Hee Jeon is a post-doctoral fellow with the McMaster University Department of Economics.

The Research Institute for Quantitative Studies in Economics and Population (QSEP) is an interdisciplinary institute established at McMaster University to encourage and facilitate theoretical and empirical studies in economics, population, and related fields. For further information about QSEP visit our web site http://socserv.mcmaster.ca/qsep or contact Secretary, QSEP Research Institute, Kenneth Taylor Hall, Room 426, McMaster University, Hamilton, Ontario, Canada, L8S 4M4, FAX: 905521 8232, Email: qsep@mcmaster.ca. The Research Report series provides a vehicle for distributing the results of studies undertaken by QSEP associates. Authors take full responsibility for all expressions of opinion. 


\title{
Joint Taxation and the Labour Supply of Married Women: Evidence from the Canadian Tax Reform of 1988
}

\author{
Thomas F. Crossley \\ Sung-Hee Jeon \\ Department of Economics, McMaster University*
}

December $2005^{* *}$

\begin{abstract}
:
The Canadian federal tax reform of 1988 replaced a spousal tax exemption with a nonrefundable tax credit. This reduced the "jointness" of the tax system: after the reform, secondary earners' effective "first dollar" marginal tax rates no longer depended on the marginal tax rates of their spouses. In practice, the effective "first dollar" marginal tax rates faced by women with high income husbands were particularly reduced. Using difference-in-difference estimators, we find a significant increase in labour force participation among women married to higher income husbands.
\end{abstract}

JEL classifications: J22, $\mathrm{H} 24$

Keywords: Labour Supply; Canadian Tax Reform; Married Women; Difference-inDifference.

\footnotetext{
* Author order is alphabetical. This paper is based, in part, on a chapter of the second author's doctoral dissertation at York University, Canada. The authors gratefully acknowledge the support of the Social and Economic Dimensions of an Aging Population (SEDAP) Research Program at McMaster University and the Social Sciences and Humanities Research Council of Canada (SSHRC). SEDAP is primarily funded by the Social Sciences and Humanities Research Council of Canada (SSHRC) and also receives substantial additional support from Statistics Canada. We also thank, without implicating, Sule Alan, Monica Singhal, YiPing Tseng and Michael Veall for very helpful comments and discussions.

** Please check http://socserv.mcmaster.ca/jeon for updates.

Correspondence: Sung-Hee Jeon, Department of Economics, KTH 424, McMaster

University, Tel: 1-905-525-9140 x.23218, Email: shjeon@mcmaster.ca.
} 


\section{Introduction}

The effect of income taxes on labour supply is a question of substantial interest to both policy makers and academics. Canadian income tax rates changed considerably during the late 80 's and early 90's; however, the effects of Canadian personal income tax reforms on labour supply have not been widely studied, particularly in comparison to personal income tax reforms in the U.S. This paper studies the effect of Canadian tax reform in 1988 on the labour supply of married women.

In his book Taxing Women (1997), McCaffery argues that the U.S. tax system significantly distorts the labour supply decisions of women. The taxation unit in the U.S. is a household - there is joint filing. If some women are secondary earners in the family, the first dollar of earnings by those married women is effectively subject to high marginal tax rates determined by their husband's income. Consequently, the joint filing limits married women's entry into the labour force. ${ }^{1}$

While the Canadian income tax system is generally based on individual taxation, particular features of the tax code have at times created incentives similar to those provided by a system of joint taxation. Given the arguments of McCaffery and others, the Canadian tax reform of 1988 is particularly interesting because it reduced the "jointness" of the tax system facing couples in Canada. That is, it eliminated a connection between a secondary earners' effective marginal tax rate and her (or his) spouse's marginal income tax rate. A spousal exemption (tax deduction) was replaced with a non-refundable tax

\footnotetext{
${ }^{1}$ The U.S. is among a small minority of developed countries with joint filing. Among the arguments for joint taxation is that it offers greater horizontal equity: two couples with the same income pay the same tax. Under a system of individual filing, the tax bill of the household depends on the how income is split between the couple.
} 
credit. The amount that can be claimed by the primary earner is in each case reduced as the secondary earner's income rises. However, because the spousal exemption reduced taxable income, its value depended on the marginal tax rate of the primary earner and was much higher for high-income (and hence high marginal tax rate) husbands. Thus, prior to the reform, a secondary earner faced a "first dollar" marginal tax rate equal to the marginal tax rate equal to her spouse's marginal tax rate (as is the case in a system of joint taxation.) This is not true with the tax credit - its value does not depend on the primary earner's marginal tax rate. Thus the effect of the reform was to significantly reduce the "first dollar" marginal tax rate of women married to high-income husbands, while leaving the "first dollar" marginal tax rate of women married to low income husbands essentially unchanged.

In this study, we follow Eissa $(1995,1996)$ and employ a difference-in-difference strategy to study the effects of taxes on female labour supply. Women married to high income men are the treated group, while women married to low income men form a control group. To implement our estimation strategy, we employ data from the Canadian Survey of Consumer Finances (SCF) for the years from 1986 to 1991. (The Canadian SCF is quite similar to the US March supplement to the CPS.) We focus on low education women, on the grounds that these women are most likely to be secondary earners.

With these data and empirical strategy we find evidence that low education women married to higher income husbands increased their labour supply and labour force participation as a result of the Canadian federal tax reform in 1988. The estimated effect on participation rates is sizeable: 9 to 10 percentage points. The implication of our results 
is that the "jointness" of tax systems may indeed be an important determinant of the labour supply of married women.

The rest of the paper is organized as follows. The next section gives further details on the Canadian tax reform of 1988 and particularly its effect on the tax rates facing married women. Section 3 places our study in the context of related literature. Section 4 gives further details on our data and methods, and Section 5 presents our results. Finally, Section 6 concludes.

\section{The Canadian Tax Reform of 1988 and Married Women}

The 1988 federal tax reforms in Canada made a number of changes to personal income tax and had a particular effect on the effective marginal income tax rates of married women. Prior to the reform, there were 10 tax brackets in the personal income tax schedule, with rates ranging from 6 to 34 percent. This was replaced with a schedule of only 3 brackets, with rates of 17,26 , and 29 percent. $^{2}$ The reform also converted personal exemptions and many tax items that were formerly deductible into nonrefundable tax credits.

For our analysis, the key change was the replacement of personal exemptions for a dependent spouse and children with a personal non-refundable tax credit. Prior to 1988, a filing spouse (usually husband) was allowed to claim a spousal exemption, which acted to reduce his taxable income which, in turn, was taxed under the bracket related schedule of rates. Under this spousal exemption husbands could claim a maximum amount of $\$ 3700$ in 1987 . The exemption however was a decreasing function of the spouse's

\footnotetext{
${ }^{2}$ However, in the Canadian tax system, effective marginal tax rates are affected by the high-income surtax, the various claw backs of refundable tax credits, and transfer payments, so that effectively, the actual number of tax brackets is larger than three.
} 
income in excess of a stated amount. Thus, for each additional dollar the spouse earned, the husband's taxable income was increased at a dollar, and this dollar was taxed at the husband's marginal tax rate.

After 1988 this spousal exemption was replaced by a non-refundable tax credit. Under the new rules, the maximum amount $(\$ 850)$ of the married or equivalent credit was reduced by 17 percent of the dependent spouse's net income in excess of $\$ 500$. This credit phased out to zero at an income level of $\$ 5500$, at which point the dependent spouse had to file a separate return. As a result, under the current Canadian tax system, a lower-income spouse faces tax rates initially at the lowest bracket rate (17 percent in 1988). In contrast, under the tax system prior to 1988 , the effective marginal tax rate of the lower-income spouse was the same as the effective marginal income tax rate of the (higher income) tax-filing spouse. For women with high income husbands, this could be much higher than $17 \%$.

Hence, if prior to 1988, the husband's marginal income tax rate was relatively high, his wife's effective marginal tax rate was considerably reduced by the tax reform. On the other hand, if the husband's marginal income tax rate was relatively low, the change in his wife's effective marginal income tax rate after tax reform in 1988 was insignificant. Therefore, our strategy is to identify the impact of the federal tax reform in 1988 on the labour supply decisions of dependent-married women as the difference between the change in labour supply of women who face large reductions in the effective marginal income tax rate (the treatment group) and the change in labour supply of women who face relatively small reductions in the effective marginal income tax rate (the control group). 
The contrast we are exploiting is very clear in Figure 1. This figure shows the preand post-reform schedule of effective marginal tax rates facing two (simulated) married women who differ only in their husbands' income (these schedules were calculated using the tax simulation program described in the appendix). The left hand side panel illustrates the marginal tax rates facing a woman whose husband has total annual income of 25,000 in 1986 Canadian dollars (as we shall see below, this is very close to the mean husband's earnings in our control group.) The right hand side panel shows the marginal tax rates of an otherwise identical woman whose husband has annual total income of 50,000 1986 Canadian dollars (this is very close to the mean in our treatment group.) ${ }^{3}$ In both cases, the pre-reform (1986) schedule of effective marginal tax rates is given by the dashed line, and the post-reform (1989) schedule is given by the solid line. The woman with the high income husband (on the right) experienced a very substantial decrease in her "first dollar" effective marginal tax rate, and indeed a substantial reduction in her effective marginal tax rates up to about 5,000 1986 Canadian dollars. In contrast, the woman with the low income husband (on the left) experienced little change in her effective marginal tax rates over the same range of income.

[Figure 1 about here]

It is also worth noting that the contrast just described is the only significant difference in the way the reform impacted these two simulated women. Both experienced the same shift and reduction in the spike above 5,000 dollars that resulted from the abrupt withdrawal of provincial tax relief for low income families. In both panels, the reduction

\footnotetext{
${ }^{3}$ The range of these figures - up to 25,000 1986 Canadian dollars in income - covers $90 \%$ of the sample we use in estimation (married women with no more than a high school education.)
} 
in the number of tax brackets is apparent. However, for both women, this results in very minor changes to the schedule of effective marginal tax rates. ${ }^{4}$

\section{Related Literature}

There is a large literature on the effect of taxes on labour supply, including women's labour supply (see for example, the survey by Blundell and MaCurdy, 1998). Among US studies of married women's labour supply, Eissa (1995) uses the differencein-difference estimation method, treating the Tax Reform Act of 1986 (TRA86) as a natural experiment. Like us, she focuses particularly on the labour supply of women married to high income husbands. The TRA86 reduced the number of tax brackets from fourteen to two. The top marginal tax rate was lowered from 50 percent to 28 percent, and the marginal tax rates of lower brackets were changed relatively less. Her study compares the changes in labour supply of women married to higher income husbands to the changes in labour supply of women married to lower income husbands. She finds that TRA86 significantly increased the labour supply of women married to higher income husbands relative to the labour supply of women married to lower income husbands. In addition, Eissa (1996) uses the Economic Recovery Tax Act (ERTA) of 1981 as a natural experiment to examine the labour supply of married women. The ERTA reduced marginal tax rates by 23 percent within each bracket over a period of three years: by 10 percent in 1982, 10 percent in 1983 and 5 percent in 1984. For two - earner married couples, ERTA introduced a tax deduction equal to 10 percent of the income of the lower

\footnotetext{
${ }^{4}$ The careful reader may notice that after the reform the control group - with low income husbands - faces slightly higher initial effective marginal tax rates than the treatment group. This is because of the phase out of a number of tax credits which are means tested on family income.
} 
earning spouse as long as he or she earned less than $\$ 30,000$. In this second study, she finds weak evidence that the labour force participation of upper income married women is responsive to taxes, and no significant evidence of an increase in labour supply (annual working hours) of upper income married women.

The difference-in-difference estimation method is distinguished by its ability to estimate labour supply responses without complete and explicit modeling of the complicated budget sets. However, Essia's studies have been criticized by Heckman (1996), Blundell and MaCurdy (1998) and Blundell, Duncan and Meghir (1998). ${ }^{5}$ The main criticism is her use of husbands' income as a "grouping variable" to assign women to treatment and control groups. The concern is that the husband's income is not exogenous and may itself respond to the tax reform. Some women may switch groups as a result of the tax reform, and such changes in group composition lead to biased estimates

\footnotetext{
${ }^{5}$ Blundell, Duncan and Meghir (1998) develop grouping instrumental variable estimators to estimate labour supply models that account for the endogeneity of gross wages and other income, and study how tax policy reforms in the UK during the 1980's affected the labour supply of married women. These grouping estimators are extensions of the difference-in-difference estimation method because they allow the consideration of more than two time periods. These two methods are very similar in the context of using differential changes between groups to control for correlation between unobservable characteristics of individuals and treatment effects (tax effects) in estimation. The differencing removes the source of endogeneity for treatment effects. Blundell, Duncan and Meghir (1998) explicitly control for the endogeneity of post tax wages using grouping instruments; therefore, the differential changes of marginal wages between groups reflect both differential growth in real wages between groups and differential impacts of the tax reforms on these groups. On the other hand, Eissa does not explicitly include a wage variable as a control variable in the differnece-in-difference estimations of labour supply. Instead, she assumes there is no differential growth in real wages between the two groups during the pre and post tax reform periods. The key difference between these two studies is the way they define their groups. Eissa uses a distribution of the husband's income as a grouping variable, which is criticized because it is also subject to tax changes. In contrast, Blundell, Duncan and Meghir (1998) use women's level of education and age cohort as grouping variables, which are exogenous (independent) of tax reforms.
} 
of the effects of the reform on labour supply behaviour. In spite of these criticisms we have adopted her identification strategy. In the next section we provide some justification for using the husband's income to determine treatment and control groups in this study.

While there is considerable research on married women's labour supply, the literature on specifically on the effects of joint-taxation is sparse. It includes policy analyses, such as McCaffery (1997), as well as more formal theoretical analyses, as in Piggott and Whalley (1996) and Apps and Rees (1999). There is little empirical work.

In one recent working paper, LaLumia (2005) uses 1940 and 1950 census data to study the U.S. switch to joint taxation in 1948. She finds a statistical significant but economically small reduction in the labour force participation of married women associated with the introduction of joint taxation (0.9-16 percentage points). While this is an important result, much has change since 1948, regarding women's expectations of labour force participation and the labour market opportunities open to them. Thus, as the Canadian economy and labour market is broadly similar to the U.S. in many respects, the Canadian tax reform of 1988 offers a complimentary opportunity to study the effects of joint taxation in a setting that, while not contemporary, is closer to the current day.

\section{Data and methods}

In this study we employ data from the Canadian Survey of Consumer Finances (SCF) for the survey years from 1986 to 1987, and from 1990 to 1991 (the survey collects income information for the proceeding year, so the actual reference years are from 1985 to 1986 and from 1989 to 1990$).{ }^{6}$ Our data are constructed from both the census family

\footnotetext{
${ }^{6}$ The SCF was collected by Statistics Canada from 1970 to 1996 and was a cross sectional data series which used a different random sample of individuals each year. In
} 
(i.e., household) files and individual files of the SCF. First, from the census family files, we select married women, whose ages are between 20 and 64 and whose husband is present and is a paid employee in the reference years. We exclude women who are self employed, ill or disabled, attending school, or whose income is the primary income for the family. Also we exclude women residing in Quebec because Quebec imposes its provincial income tax separately, complicating the calculation of marginal tax rates. The resulting sample contains 22,473 women. The census family files do not contain information on women's working hours. Thus, as the next step, we combine individual files from the SCF with the census family files using key files provided by Statistics Canada.

Arguments that joint taxation has large effects on the labour supply of married women usually invoke a "chauvinist" model of married women's labour supply in which the female partner, as secondary earner, conditions her labour supply choice on that of her husband and hence treats her husband's income as unearned income. In makes sense, therefore, to focus this study on married women for whom this model is most likely to

the mid 1990s, this survey was replaced by the Survey of Labour and Income Dynamics (SLID), a longitudinal series which followed the same individuals for several years. 
apply. ${ }^{7}$ For that reason, we restrict the sample to married women having a level of education of no more than high school. Our final sample includes 12,719 women. ${ }^{8}$

As noted above, we use total income of the husband to select the treatment and control groups. In each year, the treatment group is made up of married women whose husband's income is between the $85^{\text {th }}$ and $99^{\text {th }}$ percentile of all husbands' incomes (for that year). The 1,605 women in this group are characterized by having husbands whose total income averaged 53,273 1986 Canadian dollars. Then, we choose the control group in the following manner. First, these women must be at a point in the distribution of husbands' incomes far enough below the high income group that their marginal income tax rate does not fall by as much as the marginal income tax rates of women in the high income group. Second, these women cannot be so far down the husband's income distribution that they are fundamentally different from women in the treatment group in some unobservable way. ${ }^{9}$ On the basis of these considerations, we chose a control group of women whose husband's income is between the $21^{\text {st }}$ and the $35^{\text {th }}$ percentile of the

\footnotetext{
${ }^{7}$ We are certainly not asserting that this is the "correct" model of household labor supply, and our empirical analysis should in no way be construed as test of that proposition. Our purpose here is simply to assess empirically the impact of tax changes on the married woman's labor supply. Moreover, the set of labor supply models in which a switch from joint to individual taxation could be expected to impact female labor supply is of course much broader - for example, collective household models make an efficiency assumption which would preclude a failure to minimize joint tax liabilities. The "chauvinist" model connects us to the existing literature, is easily understood, and provides a useful focus and motivation for our empirical analysis.

${ }^{8}$ In our pre-reform data, we calculate that 52 percent of married women with less than high school qualified for joint-filing (in the sense that their husband could claim that spousal exemption). The corresponding numbers for high school graduates was 37 percent and for those with more than high school, 26 percent.

${ }^{9}$ Of course our difference-in-difference estimation strategy will handle time invariant unobservable differences - our concern here is with the plausibility of the "common trends" assumption that underlies the difference-in-difference estimator. Note that since we exclude women with more than a high school education, it seems likely that there is less variation in unobservable characteristics than in an overall sample of women.
} 
husbands' income distribution. 1,607 women belong to this control group, and the average total income of their husbands is 24,5681986 Canadian dollars. The summary statistics for the two groups are presented in Table 1. Women in the control group tend to be younger, less educated, and have more children under age 7. Also they tend to work more than the treatment group (participation, weeks and hours).

[Table 1 about here]

Turning to estimation, the following conceptual table of labour supply measures of each group before and after the tax reform motivates the difference-in-difference estimator. (Our labor supply measures will include participation or average annual working hours and annual weeks worked.)

\begin{tabular}{|l|c|c|}
\hline & Before 1988 tax reform & After 1988 tax reform \\
\hline Control group & $H_{c b}$ & $H_{c a}$ \\
\hline Treatment group & $H_{t b}$ & $H_{t a}$ \\
\hline
\end{tabular}

The changes in labor supply by women married to a higher income husband are $\left(H_{t b}\right.$ $H_{t a}$. Part of this change is due to the tax reform, and part is due to extraneous factors such as changes in labour demand. The assumption is that women married to a lower income husband (the control group) reflect these non-tax factors in the change their labor supply, given by $\left(H_{c b}-H_{c a}\right)$. This is the "common trends" assumption that underlies the difference-in-difference estimator. Thus an estimate of the effect of the tax reform on the labor supply of women in the treatment group is $\left(H_{t b}-H_{t a}\right)-\left(H_{c b}-H_{c a}\right)$. In words, we compare the labor supply growth of women who faced significant tax rate reductions to that of married women who experienced smaller (or no) tax rate reductions, under the 
assumption that in the absence of the tax reform they would have experienced the same change in labor supply.

Our analysis is based on the contrast described above and illustrated for two synthetic married women in Figure 1. Before proceeding to estimation of labor supply responses it is useful to quantify the differences in tax changes actually experienced by our treatment and control groups. Table 2 quantifies the differences in the tax schedule facing our treatment and control group, before and after the tax reform. In each case, we use only the pre-reform sample of working married women, and use our tax calculator to calculate marginal tax rates for these women, and the average tax rate of their husbands, under alternative tax scenarios. In the first column of panel a) we present estimates - for both treatment and control group - average pre-reform marginal tax rates at actual reported income; these then are our estimates of their actual marginal tax rates. In the second column of panel a), we report estimates of their (counter-factual) marginal tax rates at the same income (adjusted for inflation) if they had faced the post-reform tax schedule. The third column gives the difference in the average marginal tax rate for treatments and for controls. Finally, the fourth column reports the difference-indifference in marginal tax rates. The table illustrates a small but statistical significant (about 2 percentage points) decrease in marginal tax rates for our treatments, both absolutely and relative to controls.

However, these are working women. As Figure 1 illustrated, the principal effect of the tax reform was not to lower their marginal tax rates across the entire schedule, but rather to lower their "first dollar" marginal tax rate (by uncoupling it from their husbands marginal tax rate). We put "first dollar" in quotes because, in fact, both before and after 
the reform the marginal tax rate on the absolute first dollar of income was zero, because of a small personal exemption. What we really mean, of course, is the initial marginal tax rate facing a woman who enters the labour market in a nontrivial way.

\section{[Table 2 about here]}

To quantify this effect, we repeat the calculations of panel a), but at an income (for all women) of $1000 \$$ (in 1986 dollars). The calculations are reported in panel b) of Table 2. The average fall in the " $1000^{\text {th }}$ dollar" marginal tax rate is about seventeen percentage points, which is a very large change.

Finally, the replacement of the spousal exemption with a nonrefundable tax credit raised the average tax rates of husbands. For working married women behaving as secondary earners, this amounts to a loss in unearned income, which in turn should have an income effect on labour supply. Panel c) of Table 2 shows that there was in fact an increase in the average tax rates of the husbands of the women in our pre-reform treatment sample, but that it is quite small (about one percentage point.)

Regarding the difference-in-difference estimator, there are several concerns related to group identification. The first concern raised is finding an exogenous grouping variable. In spite of Heckman's criticisms of Eissa's approach, which are summarized in the previous section, we use the husband's total income as a grouping variable. There are several justifications for using the husband's income distribution to choose the treatment and control groups here. First, in their study of the impact of the 1988 Canadian tax reform, Sillamaa and Veall (2001) find that taxable income (including capital income) is 
substantially less responsive to tax changes in Canada than in the U.S. ${ }^{10}$ Sillamaa and Veall (2001) do find evidence of a much higher tax response in self-employment income.

Thus, we have excluded from our sample those married women having self-employed husbands, and have only kept women whose major source of total family income is wages and salaries.

Second, we use a wide income band from the husbands' income distribution to choose treatment and control groups to reduce the potential for changes in group composition across the tax reform. ${ }^{11}$ (In addition, the use of a wide band of the income distribution for control and treatment groups ensures that are enough observations in each group to produce precise estimates.)

The second concern regarding the identifying assumptions is that there are no contemporary shocks to the relative labour market outcomes over the period of the tax reforms. This includes both no relative demand and no relative supply shocks. For example, if there is a difference in wage growth between the treatment and control groups, the difference-in-difference estimates will be biased. And it is certainly possible that the wage growth rates of higher and lower educated women differed over the study

\footnotetext{
${ }^{10}$ They use similar methods to those applied by Auten and Carroll (1999) in the study of the effects of the TRA86 in the US. In contrast to the findings of Sillamaa and Veall, Auten and Carroll find both tax rates and non-tax factors appear to have had significant effects on relative income growth in the US during the late 1980s.

${ }^{11}$ Also we test using the husband's education as a grouping variable since individuals with a high level of education (more than high school) likely earn higher income, and accordingly have a high marginal tax rate in the pre tax reform period. Therefore, we identify dependent-married women who have a high marginal tax rate in the pre tax reform period as those having a husband with a higher level of education. However, the difference in changes in average marginal tax rates between women married to a higher educated husband and women married to a lower educated husband are not statistically significant - husband's education is here a weak instrument. One possible reason is that we have insufficient detail regarding husband's education in the data.
} 
period. However, our sample includes only women a high school education or less. Therefore, our analysis has less chance of being biased in this way than studies that include women of all different levels of education (such as Eissa 1995, 1996.)

A third (and related) concern regarding the difference-in-difference estimator is that the treatment and the control groups may differ in time trends of either observable or unobservable characteristics or both. ${ }^{12}$ Any bias due to differential changes in observable characteristics between the treatment and control groups is reduced in a regression adjusted difference-in-difference approach by controlling for relevant factors (Meyer 1995). Further, conditioning on additional explanatory variables via a regression adjustment will result in an efficiency improvement over estimates obtained by a simple difference-in-difference approach (Meyer 1995). Thus we augment our basic differencein-difference estimates with estimates regression-adjusted difference-in-difference estimates.

First, we estimate a probit model analyzing the binary choice of whether or not to participate in the labour force. Next, we estimate both an annual working hours equation and an annual weeks worked equation on the sample of women who are working. To control for sample selection bias in the estimation of these labour supply equations, we include an inversed Mills' ratio calculated from the participation probit. ${ }^{13}$ The participation and the labour supply equations are specified as:

\footnotetext{
${ }^{12}$ Blundell and MaCurdy (1999) also argue that given the increasing dispersion of incomes and wages among all groups during the study period of Eissa (1995), the common time effects (common trends) assumption among the unobservable components across the treatment and control groups may not be satisfied.

${ }^{13}$ As we have only one tax reform, we effectively have a single instrument, and the selection correction is identified by nonlinearities.
} 


$$
\begin{gathered}
P\left(\text { LFP }_{i t}=1\right)=\Phi\left(\beta_{0}+\beta_{1} X_{i t}+\beta_{2} \text { hdtinc }_{-} h_{i}+\beta_{3} \text { time }_{t}+\beta_{4}\left(\text { hdtinc }_{-} h^{*} \text { time }\right)_{i t}\right) \\
L S_{i t}=\alpha_{0}+\alpha_{1} X_{i t}+\alpha_{2} \text { hdtinc }_{-} h_{i}+\alpha_{3} \text { time }_{t}+\alpha_{4}\left(\text { hdtinc_ }_{-} h^{*} \text { time }\right)_{i t}
\end{gathered}
$$

where labour force participation $(L F P)$ is a latent variable that equals one if an individual is a participant, ${ }^{14} X_{i t}$ is a set of demographic variables including age, age squared, the number of preschool children dummies, level of education dummies, and provincial dummies. ' $h d t i n c_{-} h$ ' is a dummy equal to one for women in the treatment group. Any differences in labour supply preferences across the treatment and the control group are reflected in the coefficients $\beta_{2}$ and $\alpha_{2}$, in the labour force participation probit and labour supply equations respectively. Both $\beta_{2}$ and $\alpha_{2}$ are expected to be negative, because higher income women have more leisure than their lower income counterparts. The variable 'time', is equal to one for the post tax reform period. Its coefficients $\beta_{3}$ and $\alpha_{3}$ are both expected to be positive because participation and labour supply are generally increasing over time. To test the impact of the federal tax reform of 1988 , one only needs to test whether dependent-married women with a higher income spouse increased their labour supply (relative to women married to a low income spouse) after the federal tax reform. If $\beta_{4}$ and $\alpha_{4}$ are both positive, then the tax reform had a positive impact on labour force participation and labour supply respectively. This would show that the tax reform's lessening of the joint relationship between the effective marginal income tax rate of dependent-married women and of their husbands is a significant factor in a wife's labour supply decision.

\footnotetext{
${ }^{14}$ This does not include continuously unemployed married women. We redefined participation as having at least one week of work in the reference year.
} 


\section{Results}

\section{Simple Difference-in-Difference Estimates}

Table 3 reports the basic difference-in-difference estimates of the effect of the tax reform on both the labour force participation and the labour supply of married women. Panel a) compares the changes in the labour force participation of married women with husbands at higher income percentiles and married women with husbands at lower income percentiles, before and after the tax reform. The labor force participation rate of the women in the treatment group increases significantly, both relative to the control group and absolutely. The difference-in-difference estimate of the effect of the tax reform on the labor force participation rate of these women is an economically and statistically significant increase of 10 percentage points.

[Table 3 about here]

Although the primary effect of the tax reform was on the initial (or "first dollar") marginal tax rate of women in the treatment group, and this should principally affect labour supply on the participation margin, we also examine weeks worked in the reference year and annual total hours of work for employed married women. ${ }^{15}$ These calculations are reported in Panels b) and c) of Table 3. In both cases difference-indifference estimate of the effect of the tax reform is positive but not statistically significant.

Regression adjusted Difference-in-Difference Estimates

\footnotetext{
${ }^{15}$ The participation results suggest that more women are entering the labour force during this period. Because these women may be different than women in the labour force prior to tax reform, the population of working women in pre and post the tax reform may not be directly comparable.
} 
Turning to the regression results, we first present estimates of the labour force participation equation in Table 4. As expected, the number of preschool children reduces the probability of labor force participation, and more educated women are more likely to participate in the labor force. The treatment (married to high-income husbands) dummy is significantly negative. The time dummy is positive but not significant. ${ }^{16}$ The coefficient on the interaction of time and high income (which captures the effect of the tax reform) is positive and statistically significant at a $1 \%$ significance level.

[Table 4 about here]

To turn this Probit coefficient into an interpretable magnitude, we calculate the average treatment effect on the treated (the marginal effect averaged over the treatment group.) There are two ways to do this (see Blundell et al., 2004.) ATET1 is the average treatment effect on the treated given that the difference-in-difference assumption (common trends) holds for actual probabilities. ATET2 is the average treatment effect on the treated given that the difference-in- difference assumption holds for the latent index in the Probit. Both numbers, with bootstrapped standard errors, are reported in Table 5, along side the simple difference-in-difference estimate. The message of this table is that neither regression adjustment nor the method of calculating marginal effects matters very much. All three calculations indicate a statistically and economically significant increase in labor force participation of about 10 percentage points.

[Table 5 about here]

\section{Robustness and Placebo Tests}

We now report several checks on these results. Table 6.1 summarizes a number of robustness tests. In particular, we re-estimate the labor force participation probit on three

\footnotetext{
${ }^{16}$ There is sustained growth in the labour force participation of Canadian women during the 1970s and 1980s. For women aged 25-64 the labour force participation rate increased from less than 50 percent in the mid 1970s to 70 percent in the late 1980s. Then women's labour force participation rate remains around $75 \%$ throughout the 1990s (see Beaudry and Lemieux (1999) and Chaykowski and Powell (1999)).
} 
alternative estimation samples. First, we delete from our original sample of married women with a high school education or less, those who are not high school graduates. Second, we use only the 1987 and 1990 data for our "before" and "after" samples. Third, we redefine the treatment group to be women whose husbands are between the $81^{\text {st }}$ and $95^{\text {th }}$ percentile of the husbands' income distribution (this treatment group has somewhat lower incomes than our baseline treatment group.) In each case we report ATET1 and ATET2 (averages of the marginal effect of the tax reform) and associated bootstrapped standard errors. In every case the estimate of the effect of tax reform on labor force participation among our treatment group remains positive and economically and statistically significant. The estimates rage from 7 to 9 percentage points.

[Table 6.1 about here]

Table 6.2 reports the results of two "placebo tests". Ideally, we would like to have long period both before and after the reform for which we had data, and during which there were no policy reforms. A discrete change in the difference in labor force participation rates of the treatment and control group coincident with the reform - and at no other time - would be convincing evidence that we are identifying the effect of the reform. Unfortunately, we are limited in two ways. First, because of the limited availability of key files that link the individual and family files of the SCF (and hence link woman's labor supply measures to husband's income) we cannot extend our data series very far before the reform. Second, if we extend our data series much farther after the reform we encounter subsequent policy changes that may well have affected the labor force participation of married women. 
The best we can do is to calculate on difference-in-difference estimates on our two pre-reform years (1987 versus 1986) and on our two post-reform years (1991 versus 1990). In both instances we expect to find no effect - because neither of these comparisons spans a policy change (if we did find an affect, it would challenge the common trends assumption that is the basis of our empirical strategy.) Reassuringly, we do not in either case find an effect.

[Table 6.2 about here]

\section{Weeks and Hours Worked}

Finally, we report linear regression adjusted difference-in-difference estimates of the effect of the tax reform on weeks and hours worked by these (lower education) married women.

Table 7 shows the results for weeks worked in the reference year (conditional on having worked at least one week). The coefficient of time is positive, the treatment group dummy is negative and the interaction between time and treatment (which captures the effect of the reform) is positive, but none of these is significant.

Table 8 shows the results for annual total hours of work (conditional on having worked in at least one week). Having more pre-school children significantly reduces the annual total hours worked by married women. Among the low education married women in our sample, total hours of work is significantly higher for high school graduates.

Adding these controls increases both the size and significance of the interaction between treatment and the post-reform period. Across the reform, women in the treatment group increased their annual working hours by 175 hours relative to the women in the control group, and this difference-in-difference is statistically significant at a $10 \%$ level. 
Nevertheless, regression adjustment does not change the result that by far most significant effect of the tax reform on the married women in our treatment group was on the participation margin. This is unsurprising, given that the principal effect of the reform was to lower the "first-dollar" effective marginal tax rates of this group.

\section{Conclusions}

In this paper, we use difference-in-difference estimators to examine the impacts of the Canadian federal tax reform on1988 on the labour supply of married women. We focus on those with lower education, who are more likely to behave as secondary earners in their households. The federal tax reform in 1988 is interesting as a 'natural experiment' because it eliminated the connection between a married woman's effective "first dollar" marginal tax rate and her husband's income. Before the reform, a married woman secondary earner faced a "first dollar" marginal tax rate that was the "last dollar" marginal tax rate her husband. After the reform, this was not the case. Thus, for these women, the reform simulated a switch from joint to individual taxation.

We compare the labour supply of a treatment group of women married to higher income husbands to the labour supply of a control group of women married to lower income husbands. We calculate that the treatment group experienced an average reduction in their effective "first dollar" marginal tax rate of 17 percentage points, which is a very large change. The average effective "first dollar" marginal tax rate of the control group was essentially unchanged.

We find that the reform resulted in a $9-10$ percentage point increase in the labour force participation of low education women married to higher income husbands. This estimate is both economically and statistically significant, and robust to a number of 
specification checks. Regression adjusted difference-in-difference estimates also suggest a small positive effect on annual working hours.

The implication of our results is that "jointness" of tax systems may indeed be an important determinant of the labour supply of married women, particularly with those with lower education, and particularly on the participation margin. This result is of obvious interest for countries - such as the United States - with joint taxation. It should also be of interest for a number of developed countries where the unit of taxation is the individual, but where recent trends towards means testing benefits and tax credits on family income have increased the "jointness" of the tax the system.

\section{Appendix}

Taxpayers' effective marginal income tax rates differ from their statutory marginal income tax rates. Macnaughton, Matthews and Pittman $(1998)^{17}$ report that in Canada, there are nineteen separate sources of differences between effective and statutory marginal tax rates, and 56 percent of the population experiences at least some difference between effective and statutory marginal tax rates. More than one-fifth of the population has at least a ten percentage point difference between the effective and statutory tax rates. Also, they mention that high effective tax rates are concentrated in the lowest federal statutory rate bracket (17 percent). In fact more taxpayers with effective rates above 45 percent come from this bracket than from the supposedly top bracket of 31.32 percent.

\footnotetext{
${ }^{17}$ Macnaughton, Matthews and Pittman (1998) use the Social Policy Simulation Database and Model (SPSD/M), which is a database of personal income tax returns and other financial data on individuals which contains a software facility enabling the user to simulate the revenue and income distribution effects of changes to tax laws and provincial and federal social programs such as employment insurance. However, to protect confidentiality, the individuals represented on the SPSD/M are synthetic in the sense that they are composites of several similar individuals. Since it has not been originally designed for calculating marginal tax rates, there are certain difficulties associated with calculating the effective marginal tax rates. In addition, this simulation model is not comparable with other micro survey data.
} 
For the purposes of this and other work, one of us (Jeon, 2003) has developed a simulation model which calculates effective marginal income tax rates for Canada. This simulation model is distinguished from a similar application by Statistics Canada (SPSD/M) because of its ability to calculate the effective marginal tax rates of married women, including and especially, dependent tax filing spouses. This program is implemented in STATA. It was designed for use with Survey of Consumer Finances (SCF) data files but it is also compatible with other micro data sets such as the Family Expenditure Survey (FAMEX) ${ }^{18}$ and the Survey of Labour and Income Dynamics (SLID). ${ }^{19}$

This tax simulation model calculates federal and provincial tax liabilities and effective marginal income tax rates for single male and female taxpayers with or without children, as well as for married male and female taxpayers with or without children. These computations reflect the provisions of the federal and provincial income tax legislation as follows:

1) The Federal and Provincial Tax payable are computed using the rate schedules published in "The National Finances" and "Preparing your income tax returns".

2) Total income is assumed to be from either Canadian employment or Canadian taxable government transfers. Deductions are taken for CPP or QPP and UI premiums (credits are used where applicable).

\footnotetext{
${ }^{18}$ FAMEX contains reported data by survey respondents like the SCF; therefore, all information (variables) are from corresponding questions on the survey. There are several tax related variables in FAMEX: income before tax, income after tax, personal taxes (this is income tax in each year) and provincial tax credits.

${ }^{19}$ In the SLID there are two sources of income data, which depend on each respondent's preferences. Respondents can either report income sources during the interview or grant their permission for Statistics Canada to access their tax file data from Revenue Canada for purposes of the survey. In effect, well over half of SLID's income data come directly from Revenue Canada (Statistics Canada Working paper No. 94-11 "The Use of Tax File Data in the Survey of Labour and Income Dynamics: Summary Report"). In SLID, there are various variables related to income and tax information such as income tax (federal +provincial), federal income tax, provincial income tax, CPP/QPP, Child Tax Benefit, GST, etc. Also, when non-response occurs, certain types of data are imputed. Federal and provincial taxes payable are imputed using linear regression analysis, and the Child Tax Benefit and GST are imputed based on respondents' characteristics.
} 
3) For the Federal Child Tax Credit, family total income is defined as respondents' total income plus their spouses' total income. It is assumed that children under 16 (or 18 - whichever information is available in the data: SCF) have no income; therefore, the full tax savings is assigned to these children.

4) Because a refundable sales tax credit was introduced in 1986 and the GST credit was introduced in 1991, these values were reflected in the tax simulation model.

5) Provincial rates are levied as a percentage of federal rates with special flat taxes, surtaxes and low income deductions/reductions. In addition, certain tax credits issued by the provinces such as Cost Of Living Credits, and Provincial Sales Tax Credits are reflected in the program's calculations.

The program does have certain limitations. In particular, it is not well suited to calculating marginal tax rates of the self-employed, or those whose main income source is capital income. It is most suitable for calculating effective marginal tax rates of taxpayers whose main income source is employment income (wage and salaries)

\section{References}

Apps, P.F. and R. Rees, (1999), "Individual versus Joint Taxation in Models with Household Production: Comment.” Journal of Political Economy, 107(2):393403.

Auten, G. and Carroll, R. (1999), “The effect of income taxes on household income." Review of economics and statistics, 81(4), 681-693.

Beaudry, P. and Lemieux, T. (1999), "Evolution of the female labour force participation rate in Canada, 1976-1994: a cohort analysis," Canadian Business Economics, $7(2), 57-70$.

Blundell, R. and MaCurdy, T. (1999), "Labor supply: a review of alternative approaches," Handbook of Labor Economics 3, North-Holland Publishing Co.

Blundell, R., Duncan, A. and Meghir, C. (1998), "Estimation labor supply responses using tax reforms," Econometrica, 66(4), 827-861.

Chaykowski, R. P. and Powell, L. M. (1999), "Women and the labour market: recent trends and policy issues," Canadian Public Policy, 25(0), S1-25. 
Eissa, N. (1995), "Taxation and labor supply of married women: the Tax Reform Act of 1986 as a natural experiment,” NBER Working paper No.5023, National Bureau of Economic Research, Cambridge, MA.

Eissa, N. (1996), “ Labor supply and the economic recovery Tax Act of 1981,” In Empirical foundations of household taxation, edited by Feldstein, M. and Poterba, J. M., 5-32, University of Chicago Press.

Heckman, J. J. (1996), “Comment on 'Labor supply and the economic recovery Tax Act of 1981 ' by Eissa, N.," In Empirical foundations of household taxation, edited by Feldstein, M. and Poterba, J. M., 32-38, University of Chicago Press.

Jeon, S.H. (2003), Empirical Essays on Labour Supply. PhD. Dissertation, York University.

LaLumia, S., (2005), “The Effects of Joint Taxation of Married Couples on Labour Supply and Non-wage Income," Draft, University of Michigan.

Macnaughton, A., Matthews, T. and Pittman, J. (1998), "Stealth tax rates: effective versus statutory personal marginal tax rates," Canadian Tax Journal, 46(5), 10291066.

McCaffery, J. E. (1997), Taxing Women, University of Chicago Press.

Meyer, B. D. (1995), "Natural and quasi-experiments in Economics," Journal of Business and Economics Statistics, 13(2), 151-161.

Piggott, J. and J. Whalley, (1996), “The Tax Unit and Household Production.” Journal of Political Economy, 104(2):398-418.

Sillamaa, M. and Veall, M. (2001), "The effect of marginal tax rates on taxable income: a panel study of the 1988 tax flattening in Canada," Journal of Public Economics, $80,341-356$. 
Fig. 1: Married Women's Effective Marginal Tax Rates,

Pre- and Post- 1988 Tax Reform

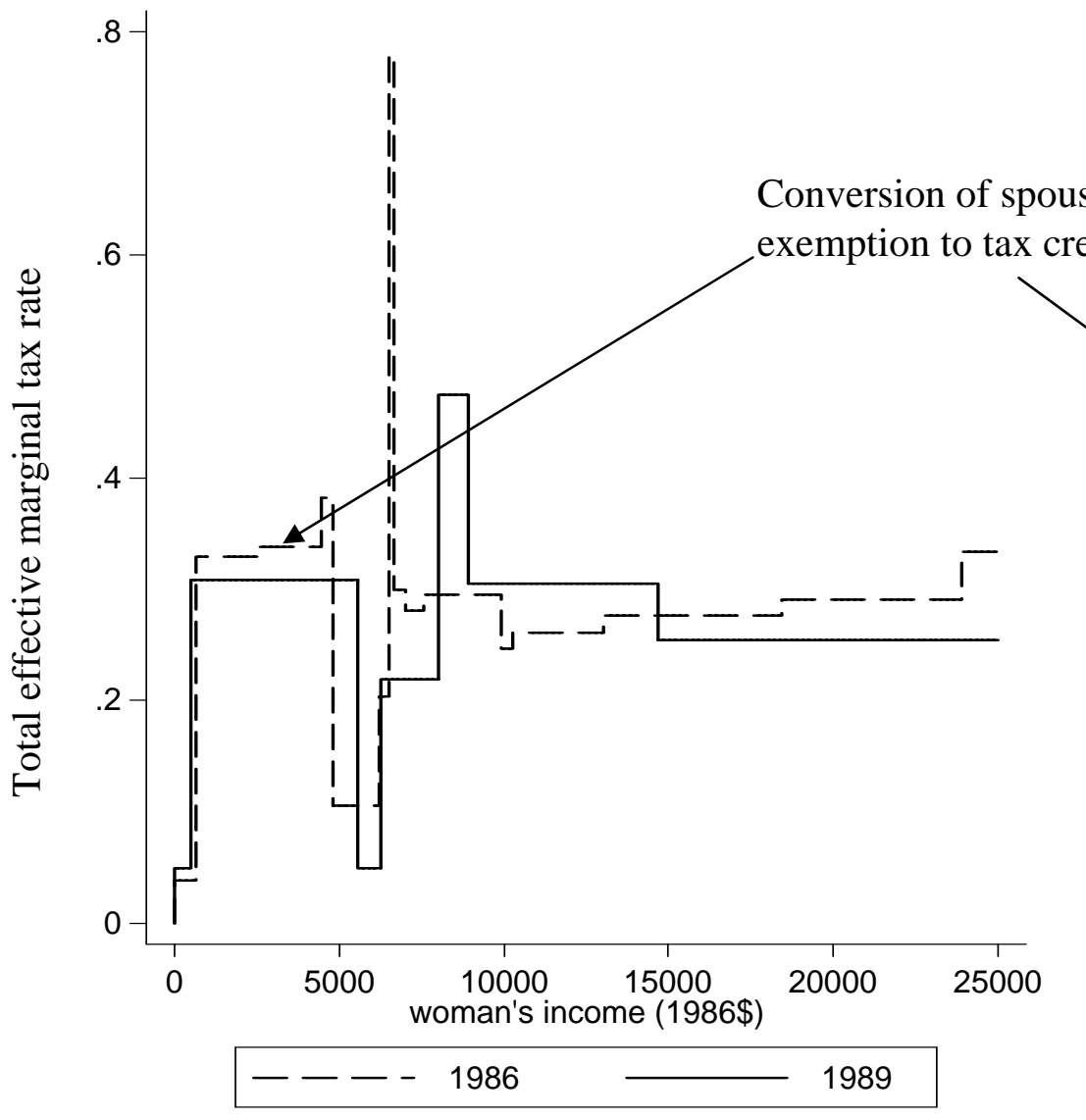

Husband's total income 25,000 (1986 \$)

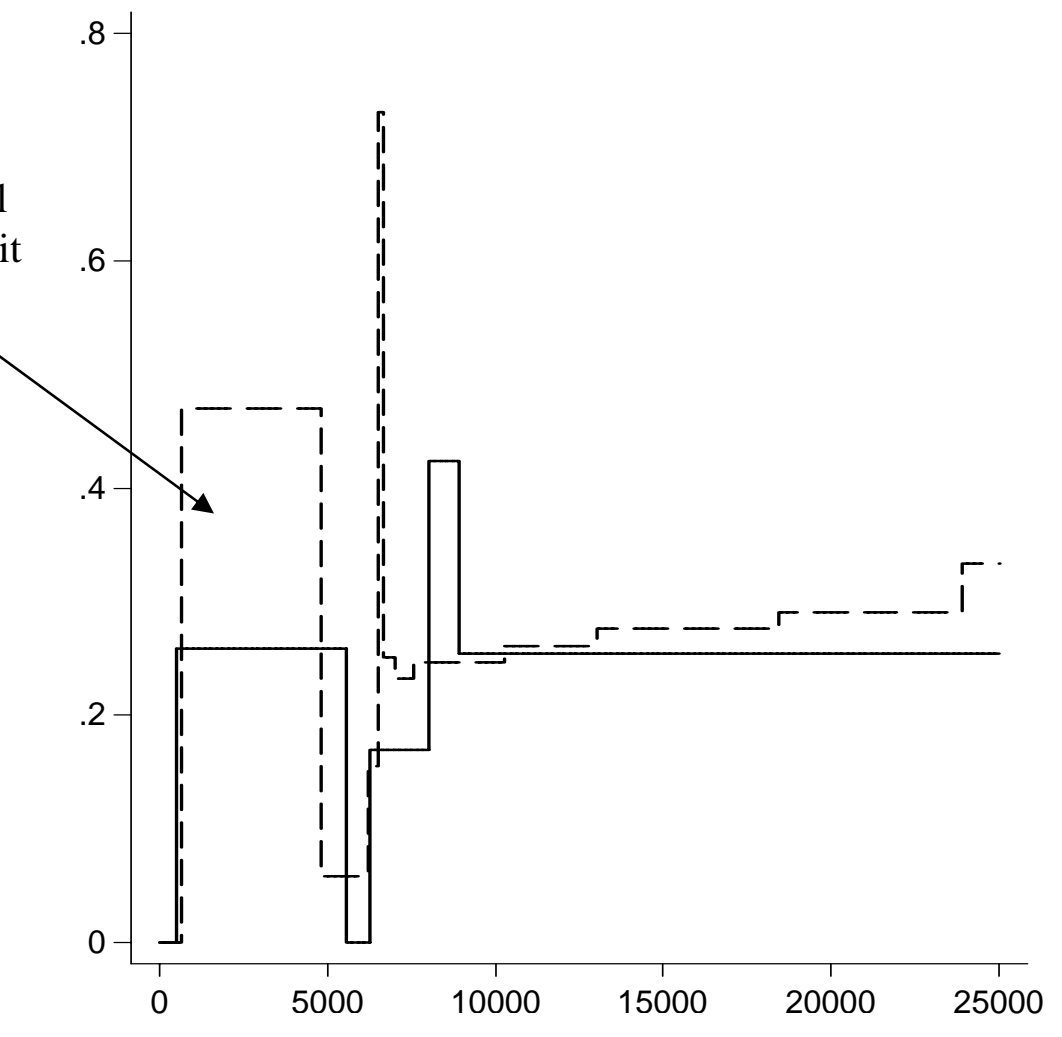

Husband's total income 50,000 (1986 \$)

Additional Details: All calculations are for a married woman from Ontario with one child under 7. She is under 65 years of age, has no pension income or disability, is not paying tuition or pursuing further education, has medical expenses less than 3\% of net income, has no charitable or similar donations and no foreign taxes paid or participation in tax-favored investments. Federal and provincial income taxes are included with all applicable surtaxes and reliefs. Unemployment Insurance and Canada Pension Plan premiums are also included as taxes. 
Table 1: Sample Characteristics,

Married Women, High School Education or Less,

Canadian Survey of Consumer Finances, 1986, '87, '90 and '91 (Pooled)

Mean (Standard error of the mean)

\begin{tabular}{lcc}
\hline & $\begin{array}{c}\text { Control Group } \\
\text { (Low Income } \\
\text { Husbands) }\end{array}$ & $\begin{array}{c}\text { Treatment Group } \\
\text { (High Income } \\
\text { Husbands) }\end{array}$ \\
\hline Age (years) & $35.1(0.2)$ & $37.9(0.2)$ \\
Pre-school children (\%) & $70.0(2.2)$ & $58.0(2.1)$ \\
High School Graduate (\%) & $52.3(1.2)$ & $67.7(1.2)$ \\
Total income (1986 \$) & $9008(193)$ & $10552(288)$ \\
Total wages (1986 \$) & $8021(188)$ & $9783(278)$ \\
Weeks worked (annual) & $32.5(0.6)$ & $29.8(0.6)$ \\
Weekly usual hours worked & $23.2(0.4)$ & $20.5(0.4)$ \\
Labor force participation (\%) & $0.71(0.01)$ & $0.65(0.01)$ \\
Husband high school graduate (but no more) (\%) & & $30.4(1.1)$ \\
Husband educated beyond high school (\%) & $28.1(1.1)$ & $44.4(1.2)$ \\
Husband's total income (1986 \$) & $26.0(1.1)$ & $53273(195)$ \\
& $24568(37)$ & \\
\hline Observations & & 1605 \\
\hline
\end{tabular}

Notes:

1. All incomes and wages are in 1986 Canadian dollars. Note that incomes refer to the previous year: for the 1986 survey, conducted in early 1986, the income refers to the previous calendar year (1985).

2. The control group consists of married women whose husbands are between the $21^{\text {st }}$ and $35^{\text {th }}$ percentile of the men's income distribution. The treatment group consists of married women whose husbands are between the $85^{\text {th }}$ and $99^{\text {th }}$ percentile of the men's income distribution. 


\section{Table 2: Effective Marginal and Average Income Tax Rates Mean (or difference in Means or Difference-in Difference in Means) (Standard error)}

a) Married women's effective total marginal income tax rates at actual pre-reform earnings

\begin{tabular}{l|cccc}
\hline Group & Pre tax reform & $\begin{array}{c}\text { Post tax } \\
\text { reform }\end{array}$ & Difference & $\begin{array}{c}\text { Difference } \\
\text { in } \\
\text { Difference }\end{array}$ \\
\hline Control & 0.279 & 0.279 & 0.000 & \\
(Low income husband) & $(0.003)$ & $(0.003)$ & $(0.004)$ & \\
\hline Treatment & 0.293 & 0.275 & $-0.017^{* * *}$ & $-0.017^{* *}$ \\
(High income husband) & $(0.004)$ & $(0.004)$ & $(0.006)$ & $(0.007)$ \\
\hline
\end{tabular}

b) Married Women's effective total marginal income tax rates at earnings of $\$ 1000$

\begin{tabular}{l|cccc}
\hline Group & Pre tax reform & $\begin{array}{c}\text { Post tax } \\
\text { reform }\end{array}$ & Difference & $\begin{array}{c}\text { Difference } \\
\text { in } \\
\text { Difference }\end{array}$ \\
\hline Control & 0.297 & 0.302 & $0.004^{* *}$ & \\
(Low income husband) & $(0.001)$ & $(0.001)$ & $(0.002)$ & \\
\hline Treatment & 0.444 & 0.273 & $-0.171^{* * *}$ & $-0.175^{* * *}$ \\
(High income husband) & $(0.002)$ & $(0.001)$ & $(0.002)$ & $(0.003)$ \\
\hline
\end{tabular}


c) Husbands' average income tax rates (at wives' actual pre-reform income)

\begin{tabular}{l|cccc}
\hline Group & Pre tax reform & $\begin{array}{c}\text { Post tax } \\
\text { reform }\end{array}$ & Difference & $\begin{array}{c}\text { in } \\
\text { Difference }\end{array}$ \\
\hline Control & 0.178 & 0.182 & $0.004^{*}$ & \\
(Low income husband) & $(0.002)$ & $(0.002)$ & $(0.003)$ & \\
\hline Treatment & 0.256 & 0.275 & $0.019 * * *$ & $0.014^{* * *}$ \\
(High income husband) & $(0.002)$ & $(0.002)$ & $(0.003)$ & $(0.004)$ \\
\hline
\end{tabular}

Notes:

1. Average and marginal tax rates are calculated for women working positive hours in the pre-reform data. The simulation model (see appendix) is used to calculate effective marginal tax rates and husbands' average tax rates. Both the pre- and post reform tax rules were applied to the same women (drawn from the pre-reform data.) Calculations were conducted both at observed earnings and at $1000 \$$ of earnings.

2. *** significantly different from zero at less than a $1 \%$ significance level (for a two tail test); ** 5\% significance level; * 10\% significance level. 
Table 3: Simple Difference-in-Difference Estimates

Mean (or difference in Means or Difference-in Difference in Means)

(standard error)

a) Labour force participation

\begin{tabular}{l|cccc}
\hline Group & Pre tax reform & Post tax reform & Difference & $\begin{array}{c}\text { Difference in } \\
\text { Difference }\end{array}$ \\
\hline Control & 0.710 & 0.709 & -0.001 & \\
& $(0.015)$ & $(0.017)$ & $(0.023)$ & \\
\hline Treatment & 0.602 & 0.700 & $0.099^{* * *}$ & $0.100^{* * *}$ \\
& $(0.016)$ & $(0.017)$ & $(0.024)$ & $(0.033)$ \\
\hline
\end{tabular}

b) Working weeks in the reference year (conditional on positive weeks)

\begin{tabular}{l|cccc}
\hline Group & Pre tax reform & Post tax reform & Difference & $\begin{array}{c}\text { Difference in } \\
\text { Difference }\end{array}$ \\
\hline Control & 45.0 & 46.8 & $1.7^{* *}$ & \\
& $(0.5)$ & $(0.5)$ & $(0.7)$ & \\
\hline Treatment & 44.9 & 47.5 & $2.5^{* * *}$ & 0.8 \\
& $(0.6)$ & $(0.5)$ & $(0.8)$ & $(1.1)$ \\
\hline
\end{tabular}


c) Annual total working hours (conditional on positive hours)

\begin{tabular}{l|cccc}
\hline Group & Pre tax reform & Post tax reform & Difference & $\begin{array}{c}\text { Difference in } \\
\text { Difference }\end{array}$ \\
\hline Control & 1509 & 1538 & 29 & \\
& $(27)$ & $(30)$ & $(40)$ & \\
\hline Treatment & 1455 & 1522 & 67 & 38 \\
& $(30)$ & $(30)$ & $(42)$ & $(58)$ \\
\hline
\end{tabular}

Notes:

1. $* * *$ difference or difference-in-difference significantly different from zero at less than a $1 \%$ significance level (for a two tail test); ** $5 \%$ significance level; * $10 \%$ significance level 
Table 4: Labor Force Participation Probit

(Regression-adjusted Difference-in-Difference)

\begin{tabular}{lcc}
\hline Variable & Coef. & Std. Err. \\
\hline Post-reform & -0.023 & $(0.070)$ \\
Treatment Group (Higher income husbands) & $-0.467 * * *$ & $(0.068)$ \\
Post-reform x Treatment Group (Tax Reform effect) & $\mathbf{0 . 2 8 1 * * *}$ & $\mathbf{( 0 . 0 9 7 )}$ \\
\hline Age & $0.035^{*}$ & $(0.020)$ \\
Age squared & $-0.001 * *$ & $(0.000)$ \\
one pre-school child & $-0.382 * * *$ & $(0.063)$ \\
two pre-school children & $-0.798^{* * * *}$ & $(0.075)$ \\
Education & & \\
$\quad$ grade 9-10 & $0.400 * * *$ & $(0.096)$ \\
$\quad$ grade 11-13, not high school graduate & $0.740 * * *$ & $(0.104)$ \\
$\quad$ grade 11-13, high school graduate & $0.762 * * *$ & $(0.089)$ \\
\hline Obs & 3212 & \\
\hline
\end{tabular}

Notes:

1. Additional covariates: province dummies.

2. $* * *$ difference or difference-in-difference significantly different from zero at less than a $1 \%$ significance level (for a two tail test); ** 5\% significance level; * $10 \%$ significance level 


\section{Table 5: Labor Force Participation:}

\section{Average Treatment Effect on the Treated}

\begin{tabular}{c|c|c}
\multicolumn{3}{c}{$\begin{array}{c}\text { Estimate } \\
\text { (standard error) }\end{array}$} \\
\hline Simple & $\begin{array}{c}\text { Regression } \\
\text { Adjusted } \\
\text { Difference- in } \\
\text { Difference -in } \\
\text { Difference } \\
\text { ATET1 }\end{array}$ & $\begin{array}{c}\text { Regression } \\
\text { Adjusted } \\
\text { Difference -in } \\
\text { Difference } \\
\text { ATET2 }\end{array}$ \\
\hline $0.100 * * *$ & $0.095 * * *$ & $0.096 * * *$ \\
$(0.033)$ & $(0.031)$ & $(0.035)$ \\
\hline
\end{tabular}

Notes:

1. The two measures of the average treatment effect on the treated are average changes in probability (marginal effects) based on the Probit model reported in Table 3. ATET1 is the average treatment effect on the treated given that the difference-in-difference assumption (common trends) holds for probabilities. ATET2 is the average treatment effect on the treated given that the difference-indifference assumption holds for the latent index. See Blundell et al. (2004)

2. Standard errors and significance tests based on 999 bootstrap replications.

3. $* * *$ significantly different from zero at less than a $1 \%$ significance level (for a two tail test);** 5\% significance level; * 10\% significance level 


\section{Table 6.1: Robustness Tests, Labor Force Participation, Average Treatment Effect on the Treated}

\begin{tabular}{l|c|c}
\hline & ATET1 & ATET2 \\
\hline Only high school graduates & $0.072 *$ & $0.073 *$ \\
& $(0.039)$ & $(0.045)$ \\
\hline Only middle years of data & $0.078^{* *}$ & $0.083 *$ \\
$(1987$ versus 1990) & $(0.042)$ & $(0.047)$ \\
\hline Alternative treatment group & $0.091 * * *$ & $0.092 * * *$ \\
(husband's income $81^{\text {st }}-95^{\text {th }}$ percentile) & $(0.030)$ & $(0.033)$ \\
\hline
\end{tabular}

\section{Table 6.2: Placebo Tests, Labor Force Participation, Average Treatment Effect on the Treated}

\begin{tabular}{l|c|c}
\hline & ATET1 & ATET2 \\
\hline Pre- reform 86 versus 87 & 0.017 & 0.004 \\
& $(0.040)$ & $(0.043)$ \\
\hline Post- reform 90 versus 91 & 0.018 & 0.022 \\
& $(0.047)$ & $(0.050)$ \\
\hline
\end{tabular}

Notes to Tables 6.1 and 6.2:

1. The two measures of the average treatment effect on the treated are average changes in probability (marginal effects) based on Probit model estimtes. ATET1 is the average treatment effect on the treated given that the difference-in-difference assumption (common trends) holds for probabilities. ATET2 is the average treatment effect on the treated given that the difference-in- difference assumption holds for the latent index.

2. Standard errors and significance tests based on 999 bootstrap replications.

3. *** significantly different from zero at less than a $1 \%$ significance level (for a two tail test);** 5\% significance level; * $10 \%$ significance level 


\section{Table 7: Working Weeks in the Reference Year, Selection Corrected Regression}

\begin{tabular}{lcc}
\hline Variables & Coef. & Std. Err. \\
\hline Post-reform & 1.01 & $(0.73)$ \\
Treatment Group (Higher income husbands) & -2.88 & $(2.78)$ \\
Post-reform x Treatment Group (Tax Reform effect) & $\mathbf{1 . 9 3}$ & $(\mathbf{1 . 9 5 )}$ \\
\hline Age & 0.05 & $(0.31)$ \\
Age squared & 0.00 & $(0.01)$ \\
one pre-school child & -2.16 & $(2.11)$ \\
two pre-school children & -4.58 & $(4.68)$ \\
Education & & \\
$\quad$ grade 9-10 & 1.81 & $(2.92)$ \\
$\quad$ grade 11-13, not high school graduate & 1.27 & $(4.75)$ \\
$\quad$ grade 11-13, high school graduate & 4.16 & $(4.81)$ \\
Inverse Mills Ratio & 6.25 & $(11.51)$ \\
Constant & $40.14 * * *$ & $(10.52)$ \\
\hline Obs & 2176 & \\
\hline
\end{tabular}

Notes

1. Additional covariates: province dummies.

2. *** significantly different from zero at less than a $1 \%$ significance level (for a two tail test); $* * \quad 5 \%$ significance level; $* 10 \%$ significance level 
Table 8: Annual Total Working Hours,

Selection Corrected Regression

\begin{tabular}{lcc}
\hline Variable & Coef. & Std. Err. \\
\hline Post-reform & 15.8 & $(40.4)$ \\
Treatment Group (Higher income husbands) & $-303.1^{* *}$ & $(145.5)$ \\
Post-reform x Treatment Group (Tax Reform effect) & $\mathbf{1 7 4 . 7 ^ { * }}$ & $(\mathbf{1 0 2 . 3 )}$ \\
\hline Age & 6.3 & $(17.2)$ \\
Age squared & -0.2 & $(0.3)$ \\
one pre-school child & $-366.1^{* * *}$ & $(112.2)$ \\
two pre-school children & $-648.5^{* * *}$ & $(246.8)$ \\
Education & & \\
$\quad$ grade 9-10 & 219.2 & $(165.6)$ \\
grade 11-13, not high school graduate & 317.2 & $(261.5)$ \\
$\quad$ grade 11-13, high school graduate & $457.3^{*}$ & $(264.5)$ \\
Inverse Mills Ratio & 949.0 & $(609.4$ \\
Constant & $1077.7^{*}$ & $(575.4)$ \\
\hline Obs & 2176 & \\
\hline
\end{tabular}

Notes

1. Additional covariates: province dummies.

2. $* * *$ significantly different from zero at less than a $1 \%$ significance level (for a two tail test); ** 5\% significance level; * 10\% significance level 
No. 367: Alternative Pasts, Possible Futures: A "What If" Study of the Effects of Fertility on the Canadian Population and Labour Force

No. 368: Baby-Boom Aging and Average Living Standards

No. 369: The Impact of Reference Pricing of Cardiovascular Drugs on Health Care Costs and Health Outcomes: Evidence from British Columbia - Volume I: Summary

No. 370: The Impact of Reference Pricing of Cardiovascular Drugs on Health Care Costs and Health Outcomes: Evidence from British Columbia - Volume II: Technical Report

No. 371: The Impact of Reference Pricing of Cardiovascular Drugs on Health Care Costs and Health Outcomes: Evidence from British Columbia - Volume III: ACE and CCB Literature Review

No. 372: Do Drug Plans Matter? Effects of Drug Plan Eligibility on Drug Use Among the Elderly, Social Assistance Recipients and the General Population

No. 373: Student Enrolment and Faculty Recruitment in Ontario: The Double Cohort, the Baby Boom Echo, and the Aging of University Faculty

No. 374: Aggregation Effects on Price and Expenditure Elasticities in a Quadratic Almost Ideal Demand System

No. 375: Age, Retirement and Expenditure Patterns: An Econometric Study of Older Canadian Households

No. 376: Location of Adult Children as an Attraction for Black and White Elderly Return and Onward Migrants in the United States: Application of a Three-level Nested Logit Model with Census Data
F.T. Denton

C.H. Feaver

B.G. Spencer

W. Scarth

M. Souare

P.V. Grootendorst

L.R. Dolovich

A.M. Holbrooke

A.R. Levy

B.J. O'Brien

P.V. Grootendorst

L.R. Dolovich

A.M. Holbrooke

A.R. Levy

B.J. O'Brien

L.R. Dolovich

A.M. Holbrook

M. Woodruff

P. Grootendorst

M. Levine

B.G. Spencer

F.T. Denton

D.C. Mountain

F.T. Denton

D.C. Mountain

B.G. Spencer

K-L. Liaw

W.H. Frey 
No. 377: The Dynamics of Food Deprivation and Overall Health: Evidence from the Canadian National Population Health Survey

No. 378: Quebec's Lackluster Performance in Interprovincial Migration and Immigration: How, Why, and What Can Be Done?

No. 379: Out-of-Pocket Prescription Drug Expenditures and Public Prescription Drug Programs

(2003)

No. 380: Population Aging, Productivity, and Growth in Living Standards

No. 381: The Transition from Good to Poor Health: An Econometric Study of the Older Population

No. 382: The Evolution of High Incomes In Canada, 1920-2000

No. 383: Population Change and Economic Growth: The LongTerm Outlook

No. 384: The Economic Legacy of Divorced and Separated Women in Old Age

No. 385: National Catastrophic Drug Insurance Revisited: Who Would Benefit from Senator Kirby's Recommendations?

No. 386: Wages in Canada: SCF, SLID, LFS and the Skill Premium

No. 387: Socioeconomic Influence on the Health of Older People: Estimates Based on Two Longitudinal Surveys

No. 388: An Invitation to Multivariate Analysis: An Example About the Effect of Educational Attainment on Migration Propensities in Japan
L. McLeod

M.R. Veall

K-L. Liaw

L. Xu

M. Qi

S. Alan

T.F. Crossley

P. Grootendorst

M.R. Veall

W. Scarth

N.J. Buckley

F.T. Denton

A.L. Robb

B.G. Spencer

E. Saez

M.R. Veall

F.T. Denton

B.G. Spencer

L. McDonald

A.L. Robb

T.F. Crossley

P.V. Grootendorst

M.R. Veall

A.L. Robb

L. Magee

J.B. Burbidge

N.J. Buckley

F.T. Denton

A.L. Robb

B.G. Spencer

A. Otomo

K-L. Liaw 
(2004)

No. 389: Financial Planning for Later Life: Subjective

C.L. Kemp

Understandings of Catalysts and Constraints

C.J. Rosenthal

M. Denton

No. 390: Exploring the Use of a Nonparametrically

F.T. Denton

Generated Instrumental Variable in the Estimation of a

Linear Parametric Equation

No. 391: Borrowing Constraints, the Cost of Precautionary Saving, and Unemployment Insurance

T.F. Crossley

H.W. Low

No. 392: Healthy Aging at Older Ages: Are Income and Education Important?

N.J. Buckley

F.T. Denton

A.L. Robb

B.G. Spencer

(2005)

No. 393 Where Have All The Home Care Workers Gone?

M. Denton

I.S. Zeytinoglu

S. Davies

D. Hunter

No. 394 Survey Results of the New Health Care Worker Study: Implications of Changing Employment Patterns

I.S. Zeytinoglu

M. Denton

S. Davies

A. Baumann

J. Blythe

A. Higgins

No. 395 Unexploited Connections Between Intra- and Intertemporal Allocation

T.F. Crossley H.W. Low

No. 396 Measurement Errors in Recall Food Expenditure Data

N. Ahmed

M. Brzozowski

T.F. Crossley

No. 397 The Effect of Health Changes and Long-term Health on

D.W.H. Au the Work Activity of Older Canadians

T.F. Crossley

M. Schellhorn

No. 398 Population Aging and the Macroeconomy: Explorations in

F.T. Denton the Use of Immigration as an Instrument of Control

B.G. Spencer 
No. 399 Users and Suppliers of Physician Services: A Tale of Two Populations

F.T. Denton

A. Gafni

B.G. Spencer

No. 400 MEDS-D Users’ Manual

F.T. Denton

C.H. Feaver

B.G. Spencer

No. 401 MEDS-E Users’'Manual

F.T. Denton

C.H. Feaver

B.G. Spencer

No. 402 Socioeconomic Influences on the Health of Older

N.J. Buckley

Canadians: Estimates Based on Two Longitudinal

F.T. Denton

Surveys

A.L. Robb

(Revised Version of No. 387)

B.G. Spencer

No. 403 Population Aging in Canada: Software for Exploring the

F.T. Denton

Implications for the Labour Force and the Productive

C.H. Feaver

Capacity of the Economy

B.G. Spencer

(2006)

No. 404 Joint Taxation and the Labour Supply of Married Women: Evidence from the Canadian Tax Reform of 1988

T.F. Crossley

S.H.Jeon 